\title{
Significance of Mangrove Biodiversity Conservation in Fishery Production and Living Conditions of Coastal Communities in Sri Lanka
}

\author{
Chaya Sarathchandra ${ }^{1,2,3,4} \mathbb{C}^{\mathbb{C}}$, Stephan Kambach ${ }^{5,6,7} \mathbb{B}^{\mathbb{D}}$, Sameera Chathuranga Ariyarathna ${ }^{8}$, \\ Jianchu Xu ${ }^{1,2,3, *}$, Rhett D. Harrison ${ }^{9}$ and Sriyani Wickramasinghe ${ }^{4}$ \\ 1 Key Laboratory for Plant Diversity and Biogeography of East Asia, Kunming Institute of Botany, \\ Chinese Academy of Sciences, Kunming 650201, China; sarathchandra@mail.kib.ac.cn \\ 2 Centre for Mountain Ecosystem Studies, Kunming Institute of Botany, Kunming 650201, China \\ 3 World Agroforestry Centre, East \& Central Asia Regional Office, Kunming 650201, China \\ 4 Department of Biological Science, Faculty of Applied Sciences, Rajarata University, \\ Mihintale 50300, Sri Lanka; sriwick@gmail.com \\ 5 Institute of Biology/Geobotany and Botanical Garden, Martin Luther University Halle-Wittenberg, \\ Am Kirchtor 1, 06108 Halle, Germany; stephan.kambach@ufz.de \\ 6 Department of Community Ecology, Helmholtz-Centre for Environmental Research, Theodor-Lieser-Str. 4, \\ 06120 Halle, Germany \\ 7 German Centre for Integrative Biodiversity Research (iDiv) Halle-Jena-Leipzig, Deutscher Platz 5e, \\ 04103 Leipzig, Germany \\ 8 Department of Zoology, Faculty of Science, University of Colombo, Colombo 00300, Sri Lanka; \\ harithasihinaya@yahoo.com \\ 9 World Agroforestry Centre, East \& Southern Africa Region, 13 Elm Road, Woodlands, Lusaka 10101, Zambia; \\ r.harrison@cgiar.org \\ * Correspondence: jxu@mail.kib.ac.cn
}

Received: 8 February 2018; Accepted: 27 March 2018; Published: 30 March 2018

\begin{abstract}
Sri Lanka is an island nation where $~ 59 \%$ of the population live in coastal regions. The main income source in these areas is fishing, which contributes to $\sim 4 \%$ of the national GDP. Fishery resources depend on mangroves, especially in estuaries and lagoons, as mangroves provide the best nursery grounds for both brackish and marine species that are significant for the island's fishing industry. However, growing pressures from an increasing population and development are causing substantial damage to mangroves resulting in loss of mangrove diversity. We analyzed whether variation in mangrove diversity within a lagoon system affects fishery production and livelihoods. Along the lagoon we selected three sites, which were $5 \mathrm{~km}$ apart from each other, for the survey. We used three $50 \mathrm{~m}$ long transects at each site for faunal and floral diversity assessments. The fishery catch was recorded from three crafts in each side. The socio-economic survey was conducted in 30 households per site using a standard questionnaire. In the site with the highest floral and faunal diversity, we also recorded the highest fish catch, but not the highest crab or shrimp catches. Our results confirm that higher mangrove diversity—and not just area-supports higher income generation. Thus, future development should prioritize biodiversity conservation in coastal regions.
\end{abstract}

Keywords: coastal development; conservation; governance; fishery; lagoons; livelihood diversity; mangrove fauna; mangrove flora; socio-economics; Sri Lanka; tropics

\section{Introduction}

Mangroves are vital tropical and subtropical coastal ecosystem, supporting a significant amount of global biodiversity and providing a wide range of ecosystem services that contribute to the well-being 
of coastal residents, especially by supporting fishery activities that provide an income for traditional and marginalized groups [1]. It is estimated that two-thirds of the world's fishing communities depend on the existence of mangroves and there is a clear positive relationship between mangrove cover and municipal fishery landing [2,3].

In a phase where global climate change is causing rising sea levels healthy mangrove forests protect the coastline. Losing these means increasing the risk of coastal subsidence, erosion, and storm damage, each of which will incur high costs in repair of the consequent damage. Despite their significance, mangroves are globally threatened by the occurrence of deforestation at alarming rates because their value to the immediate surrounding communities is often underestimated [4-6].

Sri Lanka is a tropical island with $\sim 1760 \mathrm{~km}$ coastline harbouring $\sim 1210 \mathrm{~km}^{2}$ of highly productive lagoon and estuary ecosystems $[7,8]$. Due to the very low tidal amplitude $(0.4-0.6 \mathrm{~m})$, the distribution of mangroves is confined to narrow inter tidal belts having a patchy distribution [9]. Currently Sri Lankan mangroves are estimated to cover $>4000$ ha to $>10,000$ ha and to harbour 25 true mangrove species including three endangered species Ceriops decandra (Griff.) W. Theob., Sonneratia apetala Buch.-Ham., and Lumnitzera littorea (Jack) Voigt [10-12].

Fishery is a significant coastal economic and resource use activity in marine food production and livelihoods in Sri Lanka [13]. Lagoon fishery production indicates coastal ecosystem functioning as the lagoon fish catch depends on a healthy ecosystem. Fishery resources are important assets for the gross domestic production of Sri Lanka because they still acquire major parts of income from foreign exports.

One of the major factors that threatens mangrove ecosystems in Sri Lanka is shrimp farming, which destroyed half of the mangroves in the North-Western coast in the 1990's, leading to an increase in coastal erosions and a decrease in coastal fishery production from 1992 to 2009 [7,14]. Many of these shrimp farms were later abandoned because of the White Spot Syndrome Virus (WSSV); an outbreak that dropped the shrimp exports $>65 \%$ from 1999 to 2012. To safeguard both, future fish production and mangrove health, efficient and sustainable management of the remaining mangrove ecosystems is urgently needed.

Though previous studies have already highlighted the importance of mangrove ecosystems for human sustenance [15-17] and the positive relationship between mangrove diversity and fishery production [18-20], studies that have investigated actual extent of livelihood dependence on mangroves are still limited [21]. In Sri Lanka, most of the previously published studies did either focus on mangrove diversity or the effects of shrimp aquaculture [10,22-24]. Yet, to our knowledge, no study has yet demonstrated how fishery production depends on mangrove diversity in Sri Lanka. This study attempted to fill this gap, and, by making this link, suggest policy makers on how coastal economic development and biodiversity conservation are intertwined.

Further research is required to evaluate the current conditions of mangroves in different locations, and to understand the unique uses among different communities and their role as a fishery resource in order to underpin local conservation and coastal management plans.

We conducted floristic and faunal surveys as well as fishery and community surveys in the Chilaw lagoon to provide a first quantification of the effects of mangrove diversity on the fishery catches and the occupational diversity of the resident communities of Sri Lanka. We hypothesized that the diversity of terrestrial animals as well as the catches of local fishermen would be higher in sites with higher mangrove diversity. We furthermore hypothesized that the occupational diversity of the resident communities would be positively related to mangrove diversity.

\section{Materials and Methods}

\subsection{Study Site}

The study was conducted in the Chilaw lagoon $\left(\sim 18 \mathrm{~km}^{2}\right)$ North Western Province of Sri Lanka, which has a population of $62,515\left(327 / \mathrm{km}^{2}\right)$. The majority of the population are involved in fishing and related activities $[25,26]$. Chilaw $7^{\circ} 35^{\prime} \mathrm{N} 79^{\circ} 48^{\prime} \mathrm{E}$ in the intermediate climate zone, lies $3 \mathrm{~m}$ 
above sea level, with a mean annual precipitation of $1664.3 \mathrm{~mm}$, and temperature of $27.9^{\circ} \mathrm{C}$ [27]. Mangroves in this area are fringe or riverine type, and have a rather irregular distribution along a complex of creeks [28] (Figure 1).

Mangrove diversity, fishery production, and economic surveys were conducted in three sites that varied in population density: Chilaw $\left(637.9 \mathrm{~km}^{2}\right)$, Marawala $\left(604.1 \mathrm{~km}^{2}\right)$, and Pambala $\left(570.5 \mathrm{~km}^{2}\right)$ [25]. Sites were separated by a similar distance to one another. Chilaw is the closest to the lagoon mouth having small patches of mangroves. Marawala is in the middle of the lagoon having larger patches of mangroves. Pambala is the furthest from the lagoon mouth and harbors relatively unaffected mangroves that were proposed for conservation [29].

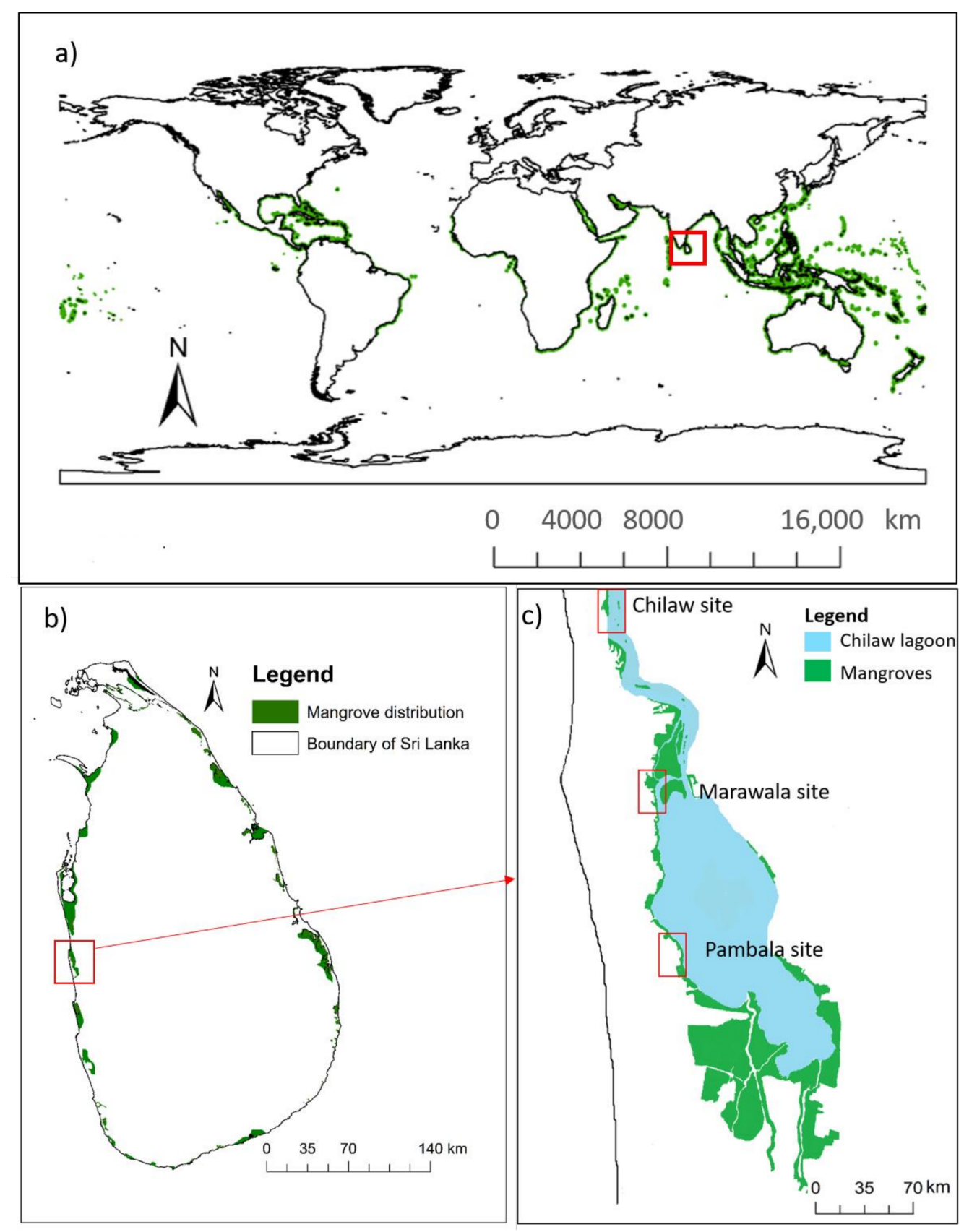

Figure 1. (a) Worldwide mangrove distribution [30] showing the location of Sri Lanka in the red colour square; (b) distribution of mangroves in Sri Lanka red square showing the location of Chilaw lagoon in North Western coast; and, (c) position of the three study sites along Chilaw lagoon. 


\subsection{Field Data Collection}

\subsubsection{Mangrove Floral and Faunal Surveys}

In each of the three study sites, we established three transects of $10 \mathrm{~m}$ width and $50 \mathrm{~m}$ length pointing inland from the shore. Floral and faunal surveys were conducted during 2013. We measured all mangroves and associated species and counted individuals with GBH (Girth at Breast Height) $>5 \mathrm{~cm}$ for our floral survey. For each mangrove species, we ascertained their conservation status from IUCN [31]. In each transect, we conducted faunal surveys diurnally once every month for twelve months, noting the occurrence of all bird, mammal, reptile, amphibian, mollusk, crustacean, and insects species. (Further details on the methodology are supplied in Supplementary Materials).

\subsubsection{Fishery Production Surveys}

Chilaw fishery district has 11 fishing villages and 9820 fishing households, with 12,220 active fishermen and 60 fish landing ports [32]. In each of the three study sites, we surveyed the catch from three crafts, i.e., from a total of nine landing port. Each port was visited once a month over the period of one year and we noted the monthly catches of fish, shrimps, and crabs.

\subsubsection{Socio-Economic Surveys}

We conducted a household questionnaire in 30 households per site, totaling 90 households. The information retrieved included the amount of income generated from fisheries, fishery related activities other income generating activities, the education level, and the occupation of each household member. We also noted the distance from each household to the nearest mangroves.

\subsection{Data Analysis}

All data analyses were conducted with $\mathrm{R}$ version 3.3.1 [33].

\subsubsection{Floral and Faunal Diversity and Fishery Catches}

For each of the three transects in each site we calculated the Shannon diversity and species evenness of the floral and faunal survey. For each of the three crafts in each site we calculated the mean monthly catch of fish, crabs, and shrimps.

$$
H^{\prime}=-\sum_{i=1}^{s} p_{i} \ln \left(p_{i}\right)
$$

$H^{\prime}=$ Shannon diversity, $s=$ number of species, $p_{i}=$ proportion of the $i$ th species.

$$
E=\frac{H^{\prime}}{H^{\prime} \max }
$$

$E=$ species evenness, $H^{\prime} \max =$ maximum possible Shannon diversity (the log of the number of species).

We tested for differences in the mean Shannon diversity and species evenness of the flora and fauna and the differences in the mean monthly catches among the three sites with separate analyses of variances (ANOVA). Significant differences were determined via Tukey's Honest Significant Test [34].

\subsubsection{Species Compositions}

Differences in composition of the flora and fauna were analysed with separate canonical (i.e., constrained) correspondence analyses (CCA). Prior to the CCA, all of the species proportions were Hellinger-transformed (i.e., square-root transformed) in order to down-weight the influence of the most abundant species. In both CCA analyses, the first ordination axis was restricted to represent the amount of variation in species compositions that can be explained by the three sites $\left(R^{2}\right)$. 


\subsubsection{Fishery Occupation and Mangrove Diversity}

Differences in the revenue and proportion of household members engaged in fishery related occupations among the three sites were tested via separate ANOVAs. We tested for a potential correlation between the revenue from fishing and the proportion of fishery-related occupations with the Kendall's tau rank-based correlation test [35].

We similarly tested for a potential correlation between the floral diversity of the mangroves and the mean occupational diversity of households via Kendall's rank based test.

\section{Results}

\subsection{Mangrove Floral and Faunal Surveys}

Across all transects, we found 16 mangrove species that were belonging to 10 families. Rhizophoraceae showed the highest abundance. Pambala was the most inland site and had the highest floral diversity $\left(H^{\prime}=2.68\right)$ with two endangered and four near threatened species (Table 1$)$.

Table 1. Mangrove plant species recorded in the three study sites, together with their conservation status and relative abundance.

\begin{tabular}{|c|c|c|c|c|c|}
\hline \multirow{2}{*}{ Family Name } & \multirow{2}{*}{ Species Name } & \multirow{2}{*}{ Conservation Status * } & \multicolumn{3}{|c|}{ Percentage Trees per Transect \% } \\
\hline & & & Pambala & Marawala & Chilaw \\
\hline \multirow[t]{6}{*}{ Rhizophoraceae } & Rhizophora mucronata Lam. & LC & 11.2 & 6.4 & 6.1 \\
\hline & Rhizophora apiculata Blume. & NT & 7.7 & 2.1 & 2.6 \\
\hline & Bruguiera cylindrica (L.) Blume & $\mathrm{EN}$ & 3.9 & 7.9 & 12.2 \\
\hline & Bruguiera gymnorrhiza (L.) Lam & VU & 3.4 & 14.3 & 10.4 \\
\hline & Bruguiera sexangula (Lour.) Poir & VU & 9.4 & 5.7 & 6.1 \\
\hline & Ceriops tagal (Perr.) C.B.Rob. & NT & 5.6 & 10.0 & 6.1 \\
\hline \multirow[t]{2}{*}{ Acanthaceae } & Avicennia officinalis L. & NT & 9.0 & 7.1 & 7.8 \\
\hline & Avicennia marina (Forssk.) Vierh. & LC & 5.6 & 10.7 & 12.2 \\
\hline Combretaceae & Lumnitzera racemosa Willd. & NT & 3.9 & 6.4 & 7.0 \\
\hline Primulaceae & Aegiceras corniculatum (L.) Blanco & $\mathrm{LC}$ & 5.6 & 0.7 & 0.0 \\
\hline Arecaceae & Nypa fruticans Wurmb & VU & 4.7 & 0.7 & 0.0 \\
\hline Pteridaceae & Acrostichum aureum L. & $\mathrm{NE}$ & 5.6 & 0.0 & 0.0 \\
\hline Lythraceae & Sonneratia alba Sm. & $\mathrm{EN}$ & 5.6 & 1.4 & 0.0 \\
\hline Euphorbiaceae & Excoecaria agallocha $\mathrm{L}$. & $\mathrm{LC}$ & 5.6 & 7.1 & 0.9 \\
\hline Acanthaceae & Acanthus illicifolius L. & $\mathrm{NE}$ & 11.6 & 19.3 & 28.7 \\
\hline Meliaceae & Xylocarpus granatum J.Koenig & LC & 1.7 & 0.0 & 0.0 \\
\hline
\end{tabular}

Faunal surveys recorded 28 species belonging to 25 families, comprising bird, crustacean, mammal, reptile, amphibian, mollusk, and insect species Table S2. The highest richness was recorded for bird species.

\subsection{Floral and Faunal Diversity and Fishery Catches}

Mean floral diversity of mangrove species was significantly different between the three study sites (Figure 2, $\mathrm{F}_{\mathrm{df} 2,6}=101.6, p<0.001^{* *}$ ). The site's diversity increased with an increasing distance to the lagoon mouth (with Chilaw being the closest and Pambala being the most distant site). The same pattern of higher Shannon diversity with increasing distance from the lagoon mouth was found in the faunal surveys, but the differences among sites were non significant (Figure 2, $\mathrm{F}_{\mathrm{df} 2,6}=2.75, p=0.14$ ). 

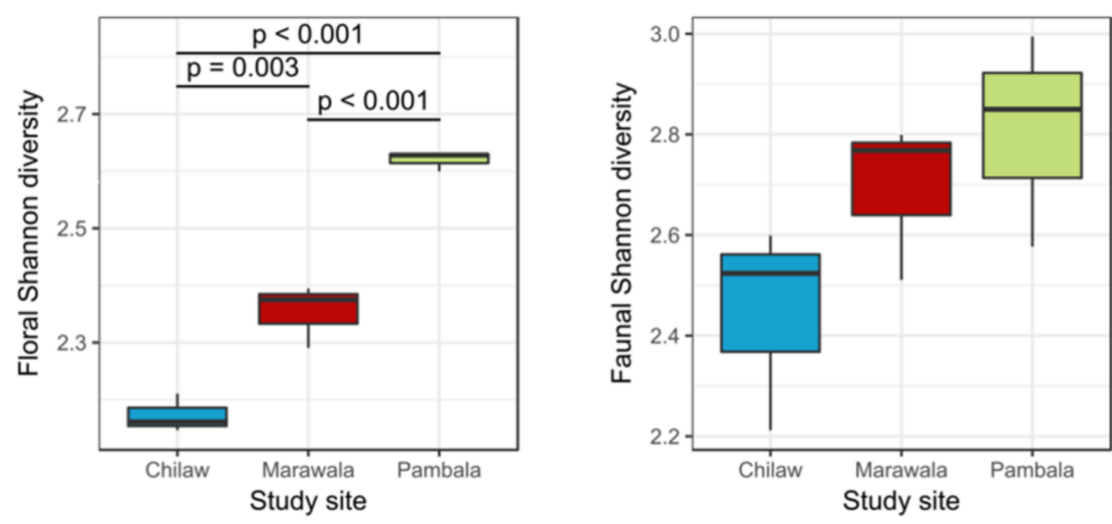

Figure 2. Mean Shannon diversity of the floral surveys (left) and the faunal surveys (right) of the three sites. $p$-values are given only for significant differences according to Tukey post-hoc test.

A total of 16 fish species belonging to 13 families were recorded in the surveyed fish catches. These included freshwater, brackish water, fresh-brackish water, and marine-brackish migratory species. More than $50 \%$ of the caught individuals belonged to one of two species: Etroplus suratensis and Liza spec. 15\% of catches consisted of marine-brackish species, such as Gerres argyreus, Caranax spp., and Lutjanus argentimaculatus that spend the first stage of their life cycle in mangroves and then move to brackish water for spawning. $7 \%$ of the catches consisted of brackish water life forms, like Siganus spp., Scatophagus argus, and Leiognathus spp.

We recorded four species of shrimps in the catches: Pinnaeus indicus, Pinnaeus semisulcatus, Pinnaeus merguensis, and Pinnaeus monodon. Shrimp catches, which fishermen prefer to fish catches because of higher selling prices per $\mathrm{kg}$ (personal communication), peaked in March and April.

Crabs were harvested throughout the year, with peak catches in November and December whereas the fewest crabs were caught in June, July and August. During the last months of the year, fishermen mostly targeted crabs because they are sold at high prices. Lagoon Crab catches mainly comprised of Scylla serrate, Portunus pelagicus and Portunus sanguinolentus. They are marine and brackish depending on the sea for part of their life cycle and the lagoon for the remainder.

Fish and crab catches differed significantly between the three sites (Figure 3, $\mathrm{F}_{\mathrm{df}: 2,6}=13.5$, $p<0.01^{* *}$ and $\mathrm{F}_{\mathrm{df}: 2,6}=6.9, p<0.05^{*}$ for fish and crabs, respectively). However, the highest number of fish were caught in Pambala and the highest number of crabs were caught in Chilaw. The post-hoc test on the differences in fishery production between each site demonstrated that for the apparent differences in shrimps catch between sites were not statistically for shrimps' significance $\left(F_{\mathrm{df}} 2,6=4.9\right.$, $p=0.05$, Figure 3).
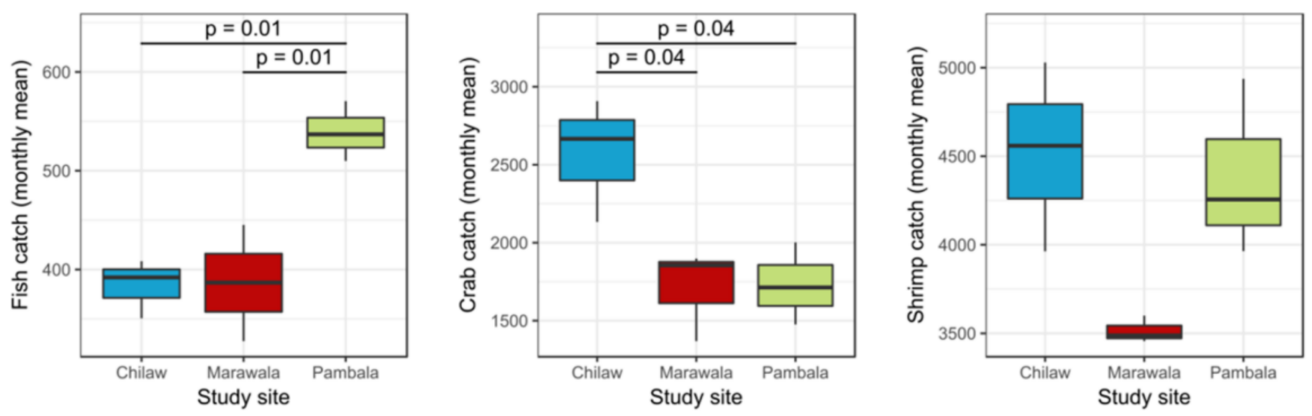

Figure 3. Mean monthly fishery catches in the three study sites, separated by fish (left) crab (middle) and shrimp (right) species. Significant differences between sites (following the Tukey post-hoc test) are indicated at the top of each boxes. 


\subsection{Species Compositions}

The three sites differed significantly in their floral and faunal composition $\left(F_{d f: 2,6}=10.73\right.$, $p<0.01^{* *}$ and $\mathrm{F}_{\mathrm{df}: 2,6}=2.55, p<0.01^{* *}$ for the floral and faunal composition, respectively). The assignment to the three sites explained a higher amount of the variation in the floral than in the faunal species composition $\left(R^{2}\right.$ adj $=0.71$ and 0.27 for the floral and faunal composition, respectively) (Figure 4).
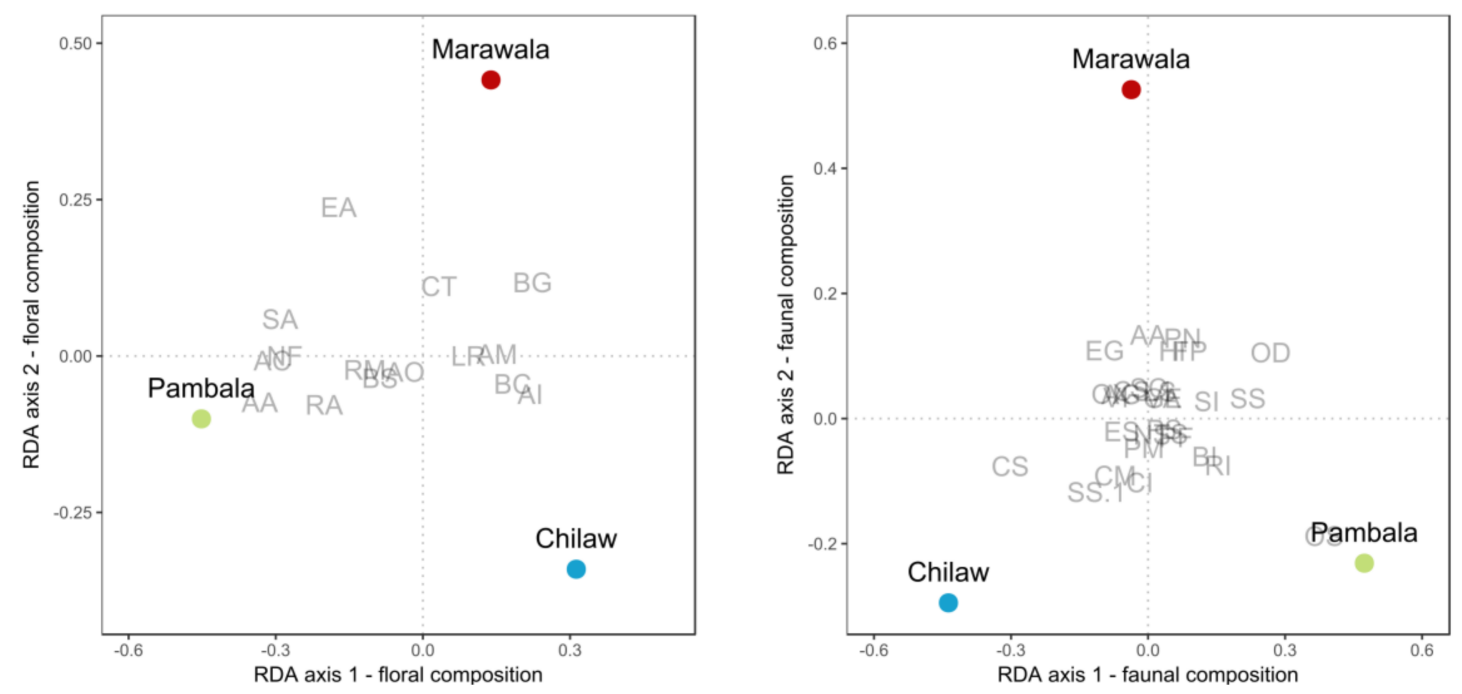

Figure 4. Results of separate constrained canonical ordinations based on the floral (left) and faunal (right) compositions in the surveyed transects of the three sites. Displayed are the first two ordination axes of which the first one was constrained to maximize the variation between the three sites (the points indicate the effects of the sites on the species composition are displayed. In the floral composition graph, we used the abbreviations in the parentheses to identify the species as Rhizophora mucronata (RM); Rhizophora apiculata (RA); Bruguiera cylindrical (BC); Bruguiera gymnorrhiza (BG); Bruguiera sexangula (BS); Ceriops tagal (CT); Avicennia officinalis (AO); Avicennia marina (AM); Lumnitzera racemosa (LR); Aegiceras corniculatum (AC); Nypa fruticans (NF) ; Acrostichum aureum (AA); Sonneratia alba (SA); Excoecaria agallocha (EA); Acanthus illicifolius (AI) and in the faunal composition graph we used the abbreviations in parentheses to identify the species as Egretta garzetta (EG); Ardeola grayii (AG); Phalacrocorax niger (PN); Alcedo atthis (AA); Corvus splendens (CS); Vanellus indicus (VI); Oriolus Xanthornus ceylonensis (OX); Funambulus palmarum (FP); Rhyothemis ingulate ingulate (RI); Brachythemis ingulatee (BI); Oecophylla smaragdina (OS); Odontomachus simillimus (OD); Scutiphora spec (SS); Tetragnatha spec (TS); Phimenes flavopictus (PF); Scylla ingula (SI); Chiromantes spec (CS); Neosarmatium spec (NS); Periophthalmus spec (PS); Littorina scabra (LS); Cassidula musterina (CM); Cerithidea ingulate (CI); Saccostrea spec (SS); Varanus alvator (VA); Ptyas mucosa (PM); Geochelone elegans (GE); Eudynamys scolopaceus (ES); Haliastur indus (HI); and, Scylla serrate (SC).

\subsection{Fishery Occupation}

Although the revenue earned from fishery and related activities were highly variable, between sites differences were not significant. The mean household revenue from fishery related occupations was similar between the three study sites. (Figure $4, \mathrm{~F}_{\mathrm{df}: 2,87}=0.6, p=0.55$ ). The proportion of household members that followed a fishing related occupation did not differ between the sites (Figure 5 , $\left.\mathrm{F}_{\mathrm{df}: 2,87}=0.7, p=0.48\right)$. 

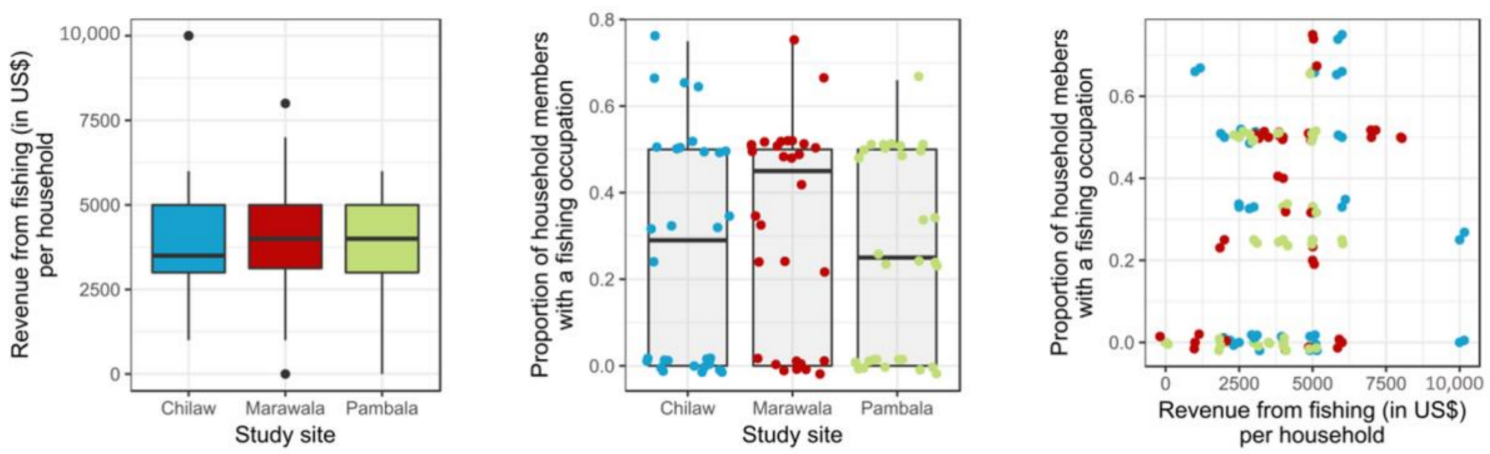

Figure 5. Mean household revenue from fishing related occupations (left) mean proportion of household members with fishing related occupations (middle). The relationship between the proportion of household members following a fishing related occupation and the household revenue from these fishing related occupations (right). Points are coloured according to the study sites.

The proportion of household members that followed a fishing occupation and the revenue from these occupations were not related, neither across all of the sites, nor within the individual study sites. (Kendall's tau $=0.16$ and $p=0.06$ across all sites and Kendall's tau $=0.02,0.25$, and 0.17, $p=0.86,0.1$, and 0.17 for the Chilaw, Marawala, and Pambala site, respectively).

\subsection{Mangrove Diversity and Occupational Diversity}

Across the three sites, we found a significant positive correlation between the Shannon diversity of the mangrove flora and the occupational diversity of the residents (Kendall's tau $=0.9$, $p<0.01^{* *}$, Figure 6). Here, occupational diversity refers to the different income generation methods of the communities.

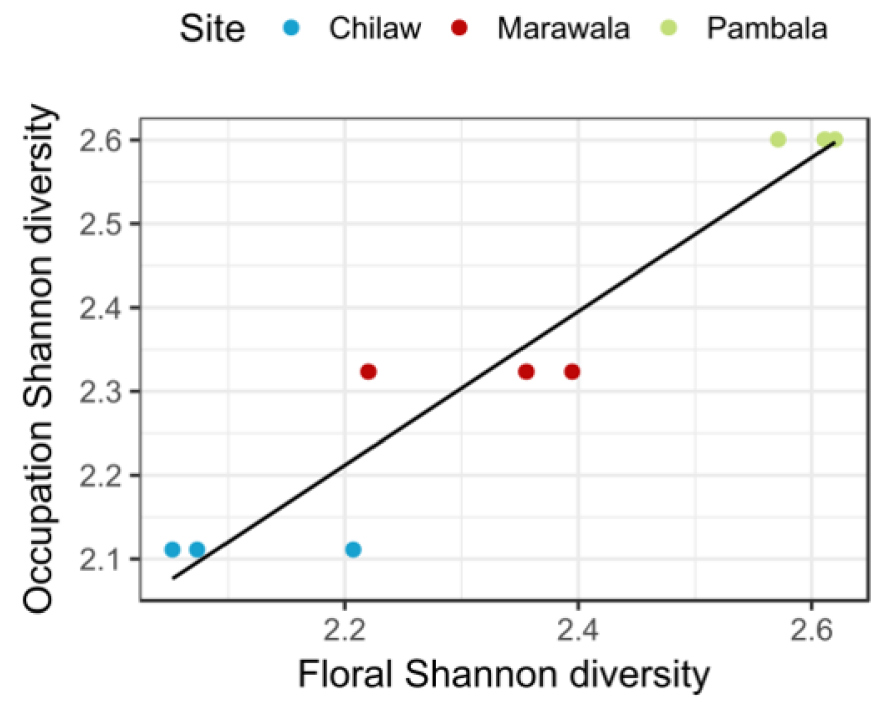

Figure 6. Relationship between the diversity of occupations in the resident communities and the Shannon diversity of the three respective sites. The solid line indicates the slope of the relationship that was obtained from a linear effects model.

\section{Discussion}

\subsection{Relationship between Mangrove Diversity and Socioeconomic Conditions}

Mangroves protect Sri Lanka's coast line from sea erosion, while providing diverse local livelihoods. Despite these important services, mangroves are cleared for substitute development 
activities that have undesirable effects on the well-being of mangrove dependent communities and the country's economy. Therefore, prior to the implementation of development activities, it is vital that the biodiversity, ecosystem services and conservation status of mangroves are assessed.

In our study, mangrove floral and faunal diversity increased from the lagoon mouth towards inland areas (Table 1 and Table S1). We found a significantly higher fish catch but not crab or shrimp catch in more diverse mangrove areas, such as Pambala. Analysis of the relationship between socio-economics and mangrove diversity showed that when an area had more diverse mangrove ecosystems, it not only had higher faunal diversity, but also had higher occupational diversity providing more income opportunities for the nearby communities. Therefore, mangroves are important to both conservation and to income diversification. The higher mangrove diversity recorded in Pambala is due to ongoing conservation activities such as mangrove restoration, awareness programs and facilitating research activities locally and internationally. Pambala site is a successful demonstration of how promoting mangrove biodiversity conservation measures are thriving the local livelihoods and meeting long term conservation goals.

Ecological theory predicts that diverse systems should be more resistant to disturbances. Thus, one might propose that conservation of mangroves could benefit biodiversity and the resistance of mangrove habitat to disturbances and the sustainability of mangrove dependent local communities [36].

\subsection{The Current Condition of the Fishery Industry}

In the study sites among the surveyed 90 families $\sim 76 \%$ directly or indirectly depended on fisheries. Lagoon fishery production is an indicator of coastal ecosystem functioning as the size of lagoon fish catch depends on healthy mangrove ecosystem. According to the fishermen in all three sites, the quantity of their catch has been drastically reduced when compared to previous years, as many of these people have being fishermen since their childhood. This fast decline of the catch that was reported by both fishermen and statistics is a result of the heavy exploitation of mangrove ecosystem and over fishing, to a degree that is threatening the long term use of these resources [14]. The high price that is offered for fishery products has attracted fishermen and outside businessmen, who harvest as much fishery products as possible irrespective of the size, age, or gender of the catch. Currently, the majority of the total landings comprise of immature and spawning stages. This highlights the importance of intact mangrove systems as nursery grounds that can safeguard future fish production.

\subsection{Increasing the Sustainability and Livelihoods of Local Fishing Communities}

Lagoon fishery products are in high demand from local consumers, as well as from large scale buyers, Chilaw's main market, where the total catch of the area is sold, is a very popular location for bulk purchases, especially for crabs and shrimps. In the market place, there are several market intermediaries who collect fish, crab, and shrimp catches from fishermen with a large profit margin. These systems could be changed and the corresponding law makers should be involved in introducing a direct market selling access to the small scale fishermen.

Local political patronage is one of the main causes for markets being weighted in favour of market intermediaries, rather than small scale producers, despite Sri Lanka being the first tropical country to have a centrally managed integrated coastal zone management program [37].

As the increasing demand for fish protein in the island and for the export market are leading to the overexploitation of fisheries resources, it is a timely concern to develop sustainable fishery and aquaculture practices [38], which will eventually be an alternative to the depletion of fishery resources and thus reduce environmental pressure by becoming a stable source of income for Sri Lankan coastal people.

Fishery resources are an asset to Sri Lanka. If managed efficiently and sustainably, they could bring in a major portion of Sri Lanka's foreign export income. Therefore, it is essential to impose legal barriers prohibiting the use of illegal devices, such as nets with small mesh size that capture immature 
stages and spawning stages of fisheries. However, if the people that are involved are not sufficiently concerned about this issue legal barriers will be insufficient to prevent over exploitation. Ultimately, if lagoon and coastal fisheries are to fail, fishermen will be the ones that are most seriously affected. Therefore, raising environmental awareness, peer education, and education through mass media and extension services is a vital step towards safeguarding these invaluable resources in Sri Lanka.

\subsection{Implications of Mangrove Biodiversity Conservation in Development Planning}

Continuing assessment of ecosystem status as in our study will help in conserving threatened ecosystems and informing government policy makers as to what level and how political interventions are necessary. Policy makers should be involved in ensuring the effective monitoring of ecosystems, arrangement of marketing facilities, and, professional training on fish catch processing techniques.

Fisheries and related activities are the major livelihoods of the majority of coastal inhabitants, and also attract considerable portion of the outside income and investment. Therefore, it is crucial to protect this resource base, as the depletion of fisheries can be potentially irreversible. Loss of the income arising from fisheries would seriously damage development within Sri Lanka. Therefore, mangrove swamps should not be seen as useless areas of vegetation to be cut down indiscriminately for aquaculture, agriculture, housing, and industrial development, but as viable resources to be developed in a sustainable manner.

A positive recent development in mangrove conservation in Sri Lanka is that the government agreed to give legal protection to the remaining mangroves of the whole island, comprising a total area of $\sim 8800$ ha and to reestablish another 3900 ha of mangroves [39]. Hopefully, this commitment will not be merely an agreement on papers, but will actually implemented on the ground.

Supplementary Materials: The following are available online at http:/ / www.mdpi.com/1424-2818/10/2/20/s1, Table S1: Summary of floral and faunal diversity indices of three sites; Table S2: Fauna observed in the three study sites; Table S3: Occupation diversity in the three study sites; Table S4: Mangrove species in Sri Lanka.

Acknowledgments: We thank Yirga Alemu, Dinesh Jayasundara, Supun Wellappuliarachchi, Dayani Shermila for their assistance with field work and Fiona R. Worthy for English language editing of the manuscript. This study was funded by the Chinese Academy of Sciences' Frontier Science Key Project (grant number QYZDY-SSW-SMC014).

Author Contributions: C.S. and S.W. conceived the ideas and designed the methodology; C.S. and S.C.A. collected the data; C.S. and S.K. analyzed the data; C.S. and S.K. led the writing of the manuscript. J.X., R.D.H., S.C.A. and S.W. revised the manuscript. All authors contributed critically to the drafts and gave final approval for submission.

Conflicts of Interest: The authors declare no conflict of interest. The founding sponsors had no role in the design of the study; in the collection, analyses, or interpretation of data; in the writing of the manuscript, and in the decision to publish the results.

\section{References}

1. Polanía, J.; Urrego, L.E.; Agudelo, C.M. Recent advances in understanding Colombian mangroves. Acta Oecol. 2015, 63, 82-90. [CrossRef]

2. Food and Agriculture Organization of the United Nations (FAO). Status and Trends in Mangrove Area Extent Worldwide; Forest Resources Assessment Working Paper No. 63; Food and Agriculture Organization of the United Nations (FAO): Rome, Italy, 2003.

3. Ronnback, P. The ecological basis for economic value of seafood production supported by mangrove ecosystems. Ecol. Econ. 1999, 29, 235-252. [CrossRef]

4. Duke, N.C.; Meynecke, J.-O.; Dittmann, S.; Ellison, A.M.; Anger, K.; Berger, U.; Cannicci, S.; Diele, K.; Ewel, K.C.; Field, C.D.; et al. A World without Mangroves? Science 2007, 317, 41-42. [CrossRef] [PubMed]

5. Ellison, A.M.; Farnsworth, E.J. Anthropogenic Disturbance of Caribbean Mangrove Ecosystems: Past Impacts, Present Trends, and Future Predictions. Biotropica 1996, 28, 549-565. [CrossRef]

6. Cunha-Lignon, M.; Kampel, M.; Menghini, R.P.; Novelli, Y.S.; Cintrón, G.; Guebas, F.D. Mangrove Forests Submitted to Depositional Processes and Salinity Variation Investigated using satellite images and vegetation structure surveys. J. Coast. Res. 2011, 1, 344-348. 
7. Harkes, I.H.T.; Drengstig, A.; Kumara, M.P.; Jayasinghe, J.M.P.K.; Huxham, M. Shrimp aquaculture as a vehicle for Climate Compatible Development in Sri Lanka. The case of Puttalam Lagoon. Mar. Policy 2015, 61, 273-283. [CrossRef]

8. Jayawickrema, S.J.C. Status of the fishery in the Chilaw lagoon. J. Natl. Sci. Found. Sri Lanka 1992, 20, $199-207$. [CrossRef]

9. Wijeratne, E.M.S.; Rydberg, L. Modelling and observations of tidal wave propagation, circulation and residence times in Puttalam Lagoon, Sri Lanka. Estuar Coast Shelf Sci. 2007, 74, 611-622. Available online: https:/ / www.sciencedirect.com/science/article/pii/S0272771407001588 (accessed on 23 December 2017). [CrossRef]

10. Jayatissa, L.P. Present Status of Mangroves in Sri Lanka, The National Read Data List of Sri Lanka: Conservation Status of Fauna and Flora; Weerakoon, D., Wijesundara, S., Eds.; Ministry of Environment: Colombo, Sri Lanka, 2012; pp. 197-199. Available online: https:/ / www.scribd.com/doc/117262646/The-National-Red-List-2012Sri-Lanka (accessed on 23 March 2017).

11. Karunathilake, K.M.B.C. Status of Mangroves in Sri Lanka. J. Coast. Dev. 2003, 7, 5-9.

12. De Silva, M.; de Silva, P.K. Status, diversity and conservation of the mangrove forests of Sri Lanka. J. South Asian Nat. Hist. 1998, 3, 79-102.

13. Joseph, L. Coastai Fisheries and Brackishwater Aquaculture in Sri Lanka; Coastal Resources Management Project of the University of Rhode Island, The Government of Sri Lanka: Colombo, Sri Lanka, 1993.

14. Ministry of Fisheries. Fish Production by Fishing Sub-Sectors, 1992-2013; Ministry of Fisheries and Aquatic Resources Development: Colombo, Sri Lanka, 2015.

15. Saenger, P. Mangrove Ecology, Silviculture and Conservation; Kluwer Academic Publishers: Dordrecht, The Netherlands, 2002.

16. Walters, B.B.; Ronnback, P.; Kovacs, J.M.; Crona, B.; Hussain, S.A.; Badola, R.; Primavera, J.H.; Barbier, E.; Dahdouh-Guebas, F. Ethnobiology, socio-economics and management of mangrove forests: A review. Aquat. Bot. 2008, 89, 220-236. [CrossRef]

17. Satyanarayana, B.; Bhanderi, P.; Debry, M.; Maniatis, D.; Fore, F.; Badgie, D.; Jammeh, K.; Vanwing, T.; Farcy, C.; Koedam, N.; et al. A socio-ecological assessment aiming at improved forest resource management and sustainable ecotourism development in the mangroves of Tanbi Wetland National Park, the Gambia, West Africa. AMBIO 2012, 41, 513-526. [CrossRef] [PubMed]

18. Boon, J.M. A socio-economic analysis of mangrove degradation in Samoa. Geogr. Rev. Jpn. 2001, 74, $159-186$. [CrossRef]

19. Feka, N.Z.; Manzano, M.G.; Dahdouh-Guebas, F. The effects of different gender harvesting practices on mangrove ecology and conservation in Cameroon. Int. J. Biodivers. Sci. Ecosyst. Serv. Manag. 2011, 7, 108-121. [CrossRef]

20. Islam, M.M.; Shamsuzzaman, M.M.; Sunny, A.R.; Islam, N. Understanding fishery conflicts in hilsa sanctuaries of Bangladesh. In Inter-Sectoral Governance of Inland Fisheries; Song, A.M., Bower, S.D., Onyango, P., Cooke, S.J., Chuenpagdee, R., Eds.; TBTI Publication Series; TBTI: St John's, NL, Canada, 2016. Available online: https:/ / www.researchgate.net/publication/304589663 (accessed on 20 October 2017).

21. Satyanarayana, B.; Mulder, S.; Jayatissa, L.P.; Dahdouh-Guebas, F. Are the mangroves in the Galle-Unawatuna area (Sri Lanka) at risk? A social-ecological approach involving local stakeholders for a better conservation policy. Ocean Coast. Manag. 2013, 71, 225-237. [CrossRef]

22. Jayasuriya, P.M.A. The distribution and the species composition of the existing mangrove vegetation around Chilaw lagoon. Vidyodaya J. Sci. 1991, 3, 103-113.

23. Satyanarayana, B.; Koedam, N.; De Smet, K.; Di Nitto, D.; Bauwens, M.; Jayatissa, L.P.; Cannicci, S.; Dahdouh-Guebas, F. Long-term mangrove forest development in Sri Lanka: Early predictions evaluated against outcomes using VHR remote sensing and VHR ground-truth data. Mar. Ecol. Prog. Ser. 2011, 443, 51-63. [CrossRef]

24. Bournazel, J.; Kumara, M.P.; Jayatissa, L.P.; Viergever, K.; Morel, V.; Huxham, M. The impacts of shrimp farming on land-use and carbon storage around Puttalam lagoon, Sri Lanka. Ocean Coast. Manag. 2015, 113, 18-28. [CrossRef]

25. Department of Census. Population by Divisional Secretariat Division and Sex, Census 2012. Available online: http:/ / www.statistics.gov.lk/page.asp?page=PopulationandHousing (accessed on 8 June 2017). 
26. Ranasinghe, T. Sustainable Financing and Benefit—Sharing Strategy for Conservation and Management of Puttalam Lagoon; For the Project: Ecologically and Socio Economically Sound Coastal Ecosystem Rehabilitation and Conservation in Tsunami Affected Countries of the Indian Ocean; International Union for Conservation of Nature (IUCN): Gland, Switzerland, 2010.

27. Department of Meteorology. Annual and Monthly Monthly Rainfall and Temperature at Observation Stations, 2010-2015. Colombo, Sri Lanka, 2016. Available online: http://www.statistics.gov.lk/Abstract2016/ CHAP1/1.6.pdf (accessed on 10 July 2017).

28. Dahdouh-Guebas, F.; Zetterström, T.; Rönnbäck, P.; Troell, M.; Wickramasinghe, A.; Koedam, N. Recent changes in land-use in the Pambala-Chilaw Lagoon complex (Sri Lanka) investigated using remote sensing and GIS: Conservation of mangroves vs. development of shrimp farming. Environ. Dev. Sustain. 2001, 4, 185-200. [CrossRef]

29. International Union for Conservation of Nature (IUCN). Conservation Management Plan for Ten Selected Mangrove Sites in Northwestern Sri Lanka; International Union for Conservation of Nature (IUCN): Gland, Switzerland, 1996.

30. International Union for Conservation of Nature (IUCN). METADATA: Digital Distribution Maps on the IUCN Red List of Threatened Species; International Union for Conservation of Nature (IUCN): Gland, Switzerland, 2014; pp. 1-5.

31. International Union for Conservation of Nature (IUCN). IUCN Sri Lanka and the Ministry of Environment and Natural Resources, the 2007 Red List of Threatened Fauna and Flora of Sri Lanka. Colombo, Sri Lanka, 2007. Available online: https:/ / cmsdata.iucn.org/downloads/rl_548_7_003.pdf (accessed on 23 December 2017).

32. Ministry of Fisheries. Basic Statistics of Marine Fisheries by Fishing District; Ministry of Fisheries and Aquatic Resources Development: Colombo, Sri Lanka, 2013.

33. R Core Team. R: A Language and Environment for Statistical Computing; R Foundation for Statistical Computing: Vienna, Austria, 2016; Available online: https:/ / www.r-project.org/ (accessed on 28 September 2017).

34. Tukey, J.W.; Cleveland, W.S. What Is the Tukey Test/Honest Significant Difference? Tukey-Kramer Method, 1st ed.; Brillinger, D.R., Ed.; Wadsworth Pub Co.: Belmont, CA, USA, 1984. Available online: https:/ / www.amazon. com/Collected-Works-John-Tukey-Probability/dp/0534033032 (accessed on 8 June 2017).

35. Kendall, M.G. Kendall Rank Correlation Coefficient. Rank Correlation. 1948. Available online: https:/ /link. springer.com/content/pdf/10.1007/978-0-387-32833-1_211.pdf (accessed on 14 September 2017).

36. Folke, C. Resilience: The emergence of a perspective for social-ecological systems analyses. Glob. Environ. Chang. 2006, 16, 253-267. [CrossRef]

37. Clark, J.R. Coastal Zone Management Handbook; Lewis Publishers: New York, NY, USA, 1996. Available online: https:/ / www.crcpress.com/Coastal-Zone-Management-Handbook/Clark/p/book/9781566700924 (accessed on 25 Augest 2017).

38. Jalaldeen, M.H.; Periyathamby, V. Alternative Resilient Livelihood Options for Fisher Folk Tsunami Victims: Special Reference to Batticaloa District of Sri Lanka; Department of Zoology, Faculty of Science, Eastern University: Sri Lanka, 2010. Available online: https:/ / www.yumpu.com/en/document/view/37052698/alternativeresilient-livelihood-option-for-fisher-folks-tsunami-victims (accessed on 30 October 2017).

39. Huxham, M. How Shrimp Farming Wreaked Havoc on Sri Lanka's Coasts. The Conversation. 2015. Available online: http:/ / theconversation.com/how-shrimp-farming-wreaked-havoc-on-sri-lankas-coasts44933 (accessed on 20 November 2017).

(C) 2018 by the authors. Licensee MDPI, Basel, Switzerland. This article is an open access article distributed under the terms and conditions of the Creative Commons Attribution (CC BY) license (http:/ / creativecommons.org/licenses/by/4.0/). 